\title{
The Strategies Research on the Development Problems of Guangxi Liuzhou's Service Industry
}

\author{
Kerong Jian \\ Library \\ Guangxi university of Science and Technology \\ Liuzhou, China \\ jkr1027@126.com
}

\author{
Zhigao Liao \\ Management Department \\ Guangxi university of Science and Technology \\ Liuzhou, China \\ liaozhigao@126.com
}

\begin{abstract}
This paper researches the development strategies of Guangxi Liuzhou's service industry. First, we try to find the insufficient problems with the current situation analysis, and through reason analysis, the reasons defeat the fast development of Liuzhou's service industry may be the orientation of industry city, insufficient investment, the lack of popularity and income. In order to develop the service industry of Liuzhou, we should change the idea, set up the concept of the secondary industry and the tertiary industry synchronization development, then to strengthen the investment environment, and create a probusiness, security business should also be taken into consideration.
\end{abstract}

Keywords- the service industry; strategies research; Guangxi Liuzhou

\section{INTRODUCTION}

Service industry is an important component of the national economy, its level of development reflects the level of development of a country. To develop modern service industry vigorously is an important way to adjust the modern economic structure, improving people's living standards, promoting the development of market economy, optimizing the allocation of social resources, and improving the overall effectiveness and efficiency of the national economy.

The Twelfth Five Year Plan is the critical period for the Guangxi scientific development, harmonious development, leapfrog development and to achieve the "wealthy and strong Guangxi" Strategies. Accelerate the development of modern service industry is the only way to promote economic restructuring, and accelerate the transformation of economic growth mode for Liuzhou.

\section{THE CURRENT SITUATION ANALYSIS}

In 1978, Liuzhou services added value only 2.3 billion, and exceeded 100 billion Yuan in 2001. "The Eleventh Five-Year", Liuzhou overcame the financial crisis, accordance with the "economic upgrading, urban transformation" approach, the city's service industry is entering a period of rapid growth. In 2006 the added value of tertiary industry exceeded 200 billion Yuan, and exceeded 400 billion yuan in 2011.

In period of the Eleventh Five-Year, the city's tertiary industry added value was 18.695 billion yuan in 2005 and rose to 36.587 billion yuan in 2010 (Table I), with an annual growth rate of $10.53 \%$, lower than the average annual GDP growth rate of 4.85 percentage points, and lower than the industry average annual growth rate of 9.6 percent. The tertiary industry investment in fixed assets was 59.823 billion yuan, which own to the total social fixed assets investment $59.53 \%, 2.75$ times that of 2005.The tertiary industry employment ability is enhanced, the tertiary industry employment increased from 688900 in 2005 to 705600 in 2010.

TABLE I. 2005 - 2011 IN LIUZHOU CITY, THE TERTIARY INDUSTRY ADDED VALUE AND GROWTH COMPARED TO THE SAME PERIOD

\begin{tabular}{|c|c|c|}
\hline Year & $\begin{array}{c}\text { the tertiary industry added value } \\
\text { (Billion yuan })\end{array}$ & $\begin{array}{c}\text { Year on year growth } \\
(\%)\end{array}$ \\
\hline 2005 & 186.95 & 11.61 \\
\hline 2006 & 210.79 & 9.29 \\
\hline 2007 & 240.00 & 12.24 \\
\hline 2008 & 276.08 & 9.01 \\
\hline 2009 & 319.18 & 12.4 \\
\hline 2010 & 365.87 & 9.76 \\
\hline 2011 & 418.66 & 7.8 \\
\hline
\end{tabular}

In 2011 the city of the tertiary industry added value of 418.66 billion yuan, a year-on-year increase of $7.8 \%$, lower than the GDP growth rate of 2.8 percentage points, 4.3 percentage points lower than the growth rate of industry; three industry proportion is: 8.67:64.68:26.65 (Table 2).

TABLE II. 2005 - 2011 IN LIUZHOU CITY, THE THREE INDUSTRIES ACCOUNTED FOR THE PROPORTION OF GDP (UNIT:\%)

\begin{tabular}{|c|c|c|c|c|}
\hline Year & $\begin{array}{c}\text { The first } \\
\text { industry }\end{array}$ & $\begin{array}{c}\text { The } \\
\text { secondary } \\
\text { industry }\end{array}$ & $\begin{array}{c}\text { industrial } \\
\text { value-added }\end{array}$ & $\begin{array}{c}\text { The tertiary } \\
\text { industry }\end{array}$ \\
\hline 2005 & 11.51 & 51.97 & 47.22 & 36.51 \\
\hline 2006 & 10.57 & 55.56 & 51.37 & 33.87 \\
\hline 2007 & 10.22 & 57.99 & 53.97 & 31.78 \\
\hline 2008 & 9.45 & 60.06 & 55.87 & 30.50 \\
\hline 2009 & 8.65 & 60.84 & 56.22 & 30.51 \\
\hline 2010 & 8.32 & 63.86 & 59.06 & 27.82 \\
\hline 2011 & 8.67 & 64.68 & 59.56 & 26.65 \\
\hline
\end{tabular}


In recent years, Liuzhou City, the tertiary industry accounted for the proportion of GDP is low and leading a declining trend. Compared with the second industry, the proportion of the tertiary industry in Liuzhou in the GDP shows "running track steadily - gradually falling". It can divided into two phases: boost phase of $1978-2001$ and the gradually decline stage which from the beginning of 2002. In 2001 in Liuzhou City, the tertiary industry accounted for the proportion of GDP has hit a record high of $43.87 \%$. As a result of industrialization, accelerated marketization process, the tertiary industry proportion has continued to decline, falling to $27.82 \%$ in 2010 , continued to decline in 2011 to $26.65 \%$ (Table II).

Compared with the same scale city in the region, such as Nanning city, Guilin city, and the average level of the region, Liuzhou city is relatively backward. 2011 in Liuzhou City, the tertiary industry added value accounted for the proportion of GDP is $26.65 \%$, below the Guangxi average of 6.9 percentage points, lower than the national average of 16.45 percentage points, respectively, lower than the Nanning City, Guilin 21.23 percentage points and 8.35 percentage points respectively (Table III).

TABLE III. 2011 IN LIUZHOU CITY, THE TERTIARY INDUSTRY INCREASED VALUE AND PARTIAL CITY CONTRAST AREA

\begin{tabular}{|c|c|c|c|c|c|c|}
\hline \multirow{2}{*}{ Area } & \multicolumn{2}{|c|}{$\begin{array}{l}\text { The added value } \\
\text { of the tertiary } \\
\text { industry } \\
\text { (Billion Yuan) }\end{array}$} & \multicolumn{2}{|c|}{$\begin{array}{c}\text { The tertiary } \\
\text { industry added } \\
\text { value growth } \\
\text { rate } \\
(\%)\end{array}$} & \multicolumn{2}{|c|}{$\begin{array}{l}\text { The added value of } \\
\text { the tertiary industry } \\
\text { accounted for the } \\
\text { proportion of GDP } \\
(\%)\end{array}$} \\
\hline & Total & Ranking & $\begin{array}{c}\text { Year } \\
\text { on } \\
\text { year } \\
\text { growth }\end{array}$ & Ranking & proportion & Ranking \\
\hline Nanning & 1058.85 & 1 & 11.1 & 3 & 47.88 & 1 \\
\hline Liuzhou & 418.66 & 3 & 7.8 & 9 & 26.65 & 10 \\
\hline Guilin & 467.58 & 2 & 7.9 & 8 & 35.00 & 2 \\
\hline Guangxi & 3930.27 & & 9.4 & & 33.55 & \\
\hline
\end{tabular}

Compared with the outer area similar city, the tertiary industry added value, growth, accounted for the proportion of GDP of Liuzhou were all lower than Guangdong Zhongshan, and Zhejiang Huzhou city (Table IV). The development of Liuzhou City, the tertiary industry still has growth slow, small volume, low proportion of problems.
TABLE IV. 2011 THE TERTIARY INDUSTRY ADDED VALUE COMPARISON BETWEEN LIUZHOU CITY AND THE EXTERNAL PART OF GUANGXI PROVINCE

\begin{tabular}{|l|c|c|c|c|}
\hline \multicolumn{1}{|c|}{ City } & $\begin{array}{c}\text { The } \\
\text { added } \\
\text { (BDPllion } \\
\text { Yuan) } \\
\text { the } \\
\text { tertiary } \\
\text { industry } \\
\text { (Billion } \\
\text { Yuan) }\end{array}$ & $\begin{array}{c}\text { The } \\
\text { tertiary } \\
\text { industry } \\
\text { added } \\
\text { value } \\
\text { growth } \\
\text { rate } \\
\text { (\%) }\end{array}$ & $\begin{array}{c}\text { The added } \\
\text { value of the } \\
\text { tertiary } \\
\text { industry } \\
\text { accounted for } \\
\text { the } \\
\text { proportion of } \\
\text { GDP } \\
\text { (\%) }\end{array}$ \\
\hline Guangxi Liuzhou & 1571.02 & 418.66 & 7.8 & 26.65 \\
\hline $\begin{array}{l}\text { Guangdong } \\
\text { zhongshan }\end{array}$ & 2190.82 & 909.19 & 12.9 & 41.50 \\
\hline Zhejiang Huzhou & 1518.83 & 578.26 & 13.5 & 38.07 \\
\hline Hunan zhuzhou & 1563.9 & 485.1 & 11.4 & 31.02 \\
\hline Sichuan Mianyang & 1189.1 & 373.3 & 9.9 & 31.39 \\
\hline Neimenggu Baotou & 3005.4 & 1260.05 & 13.9 & 41.93 \\
\hline
\end{tabular}

\section{THE REASON ANALYSIS}

In recent years, although the tertiary industry of Liuzhou has developed rapidly, it is not consistent with the overall level of development and the economic society, which caused by both external factors and internal factors. In addition to the environment of an industrial city, the slow development of the tertiary industry of Liuzhou also has many other causes, such as out-dated ideas, insufficient consumption, weak industry, bad developing environment, nun- comprehensive Statistics, which restricting the development of the tertiary industry of Liuzhou.

Finally, complete content and organizational editing before formatting. Please take note of the following items when proofreading spelling and grammar:

\section{A. The orientation of industry city lags the development of the tertiary industry}

Liuzhou is a traditional industrial city, and its industrial culture caused that Liuzhou city attaches great importance to the industrial development far more than the tertiary industry. Land, capital, policy, projects and talent are also inclined to industry. Relative to the rapid industrial development in Liuzhou, the development of the tertiary industry is obviously lagged. In 2011 the city's industrial added value accounted for the proportion of GDP is $59.56 \%$, and the tertiary industry is only $26.65 \%$.

\section{B. Insufficient investment}

Before the service industry revitalization of the general assembly held in 2012, the funds was only about 10 million yuan annually for the development of the tertiary industry in Liuzhou. Even the support funds for the service industry after the assembly rose to 40 million yuan, and may be gradually increasing, compared with the industry at 100 million yuan, the investment is still insufficient. In addition, due to financial and 
the concept of local area restrictions, the county level government input in support of the tertiary industry development funds are less, resulting in service industry projects advancing slowly, the introduction of leading enterprises in the service sector is not enough, to support and reward outstanding service enterprises is insufficient and so.

\section{The lack of popularity and income does not lead to higher consumption ability}

At present, the overall consumption of Liuzhou city is, from 2006 to 2011, Liuzhou total retail sales of social consumer goods growth has increased at first and then decreased, the total retail sales of consumer goods accounted for the proportion of GDP also increased first and then decreased. Thus, the overall level of consumption of Liuzhou city is still relatively low, attract foreign consumption ability is weak, the local resident consumption desire is not strong, the level of consumption decline.

\section{STRATEGIES RESEARCH ON THE DEVELOPMENT PROBLEMS OF GUANGX AND SUGGESTIONS}

\section{A. Change the idea, set up the concept of the secondary industry and the tertiary industry synchronization development}

The development of the tertiary industry is to promote the further development of the important support of the first industry and the secondary industry. Transportation, warehousing, trade and other sectors of the tertiary industry, provide the external for the first industry and the secondary industry development condition of the task. With the development of national economy gradually turned to the intensification and socialization, the development of the first industry and the secondary industry will increasingly rely on the tertiary industry can provide information, timely updated technology, excellent service and applicable talents. Only one industry, will artificially manufacturing development short legs, not only can improve the social economic benefit, but also will lead to enormous waste of resources.

The Liujiang County's emerging industrial park and Liucheng county's Liu tang Industrial Park, have been and are facing industrial enterprise recruitment difficult problems. Investigate its reason, because for the industry supporting the tertiary industry development can not keep up with the situation, the urbanization lags behind industrialization. The more far away from the town industrial park, more prominent contradictions between them.

\section{B. To strengthen the investment environment, to create a pro business, security business}

One is to strengthen infrastructure construction. The construction of city should have traffic convenient communications. To speed up the building of modern urban traffic system, focus on the construction of city transportation network; to accelerate the "Liuzhou - Sanjiang" highway construction; actively promote the Liuzhou section of the Liu zhou-Zhao Qing railway and the Guiyang-Guangzhou railway Nanning-Liuzhou's passenger dedicated line expansion renovation construction; accelerate the airport expansion work, increase route development efforts, strive to make Liuzhou airport, Guangxi has become the third largest airport. Speed up the internal traffic construction. To accelerate the development of Liuzhou urban and rural integrated transportation system; strengthen guidance services and facilities for tourist traffic input, and gradually perfect the construction of tourist traffic sign system, highway service area to expand tourism services; to speed up the construction of traffic Liubei, especially road construction to important scenic area, improving the status of Liubei's tourism traffic. Further to support the city roads, water and electricity, landscaping and other infrastructure construction. Two is to strengthen the construction of the soft investment environment. Improving administrative efficiency and the traffic conditions, strengthen the management of social order, reducing the threshold for entering the industry, perfecting the employment medical security implementation of the series of soft environment construction measures. Formation "everyone is investment environment, everyone is the builder of the investment environment $r$ ", and create a pro business, security business atmosphere.

\section{ACKNOWLEDGEMENTS}

This research was supported by the science foundation of Guangxi University of science and Technology (Grant no. 1307220) and the Doctor Fund of Guangxi University of science and Technology (Grant no. S1103).

\section{REFERENCES}

[1] Ruud Smits, Innovation studies in the $21^{\text {st }}$ century: Questions from a user' s perspective, Technological Forecasting and Social Change, 69(2002), 861-883

[2] Emmanuel Muller, Andrea Zenker, Business services as actors of knowledge transformation:the role of KIBS in regional and national innovation systems, Research Policy, 30(2001) 1501-1516

[3] 14.Roy Rothwell, Towards the fifth-generation innovation process, International Marketing Review, 11(1)(1994), 7-31

[4] 15.Yuan-Chieh Chang. Ming-Huei Chen, Comparing approaches to systems of innovation: the knowledge perspective, Technology in Society, 26(2004), 17-37

[5] Xu Jiuping, Liao Zhigao, Zhineng Hu, A classof linear differential dynamical systems with fuzzy initial condition. Fuzzy Sets and Systems 158(2007) 2339-2358

[6] Jiuping $\mathrm{Xu}$, Zhigao Liao, Juan J. Nieto. A class of lineardifferential dynamical systems with fuzzy matrices. Journal of Mathematical Analysis and Applications 368(2010) 54-68

[7] Zhigao Liao, Jiuping $\mathrm{Xu}$, Liming Yao, A Dynamical Innovation Diffusion Model with Fuzzy Coefficient and Its Application to Local Telephone Diffusion in ChinaDiscrete Dynamics in Nature and Society, Volume 2013, Article ID 148398, 17 pages 